\title{
THE EFFECT OF INORGANIC OR ORGANIC ZINC ON THE MORPHOLOGY OF THE INTESTINE IN BROILER CHICKENS
}

\author{
Levkut, M., Jr. ${ }^{1}$, Fukasová, M. ${ }^{1}$, Bobíková, K. ${ }^{1}$ \\ Levkutová, M. ${ }^{1}$, Čobanová, K. ${ }^{2}$, Levkut, M. ${ }^{1,3}$ \\ ${ }^{1}$ University of Veterinary Medicine and Pharmacy, Košice \\ ${ }^{2}$ Institute of Animal Physiology of the Slovak Academy of Sciences, Košice \\ ${ }^{3}$ Neuroimmunological Institute of the Slovak Academy of Sciences, Bratislava \\ Slovakia \\ martin.levkut@uvlf.sk
}

\section{ABSTRACT}

This study compared the effect of dietary supplementation with an inorganic or organic zinc source on the gut morphology in the jejunum of broilers. One-day-old chickens were fed a basal diet (Control group: BD -

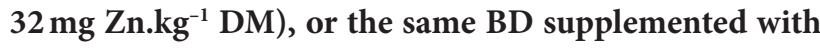
$30 \mathrm{mg}$ or $70 \mathrm{mg}$ of $\mathrm{Zn}$ per $\mathrm{kg}$ of $\mathrm{DM}$ in the form of $\mathrm{ZnSO}_{4}$. $\mathrm{H}_{2} \mathrm{O}$ (Group 1: $30 \mathrm{mg} \mathrm{ZnSO}$; Group 2: $70 \mathrm{mg} \mathrm{ZnSO}_{4}$ ), and $30 \mathrm{mg}$ or $70 \mathrm{mg}$ of $\mathrm{Zn}$ per $\mathrm{kg}$ of DM in the form of zinc chelate of glycine hydrate (Group 3: $30 \mathrm{mg} \mathrm{Zn}-\mathrm{Gly}$; Group 4: $70 \mathrm{mg} \mathrm{Zn}$-Gly) for 40 days. The villus height was increased in the groups which received $30 \mathrm{mg} \mathrm{ZnSO}_{4}$ and $70 \mathrm{mg} \mathrm{ZnSO}_{4}$ and or $70 \mathrm{mg} \mathrm{ZnSO}_{4}$, as compared to the $\mathrm{BD}$ and $30 \mathrm{mg} \mathrm{Zn}$-Gly. The villus surface was higher in all groups receiving the $\mathrm{Zn}$ supplements in comparison to the $\mathrm{BD}$.

Key words: chickens; intestine; morphometry; zinc

\section{INTRODUCTION}

The nutritional importance of zinc has been known for a long time, but in the past decades its importance in immune modulation has gained increased recognition. Zn can come from organic or inorganic sources. The organic forms of zinc include: amino acid chelates, bioplexes, proteins, as well as lactates and acetates. Zinc from amino acid complexes has been reported to be more bioavailable than $\mathrm{Zn}$ from the inorganic sources $[1,15]$. Zinc-glycin (Zn-Gly) complex has a slightly higher stability constant for $\mathrm{Zn}$ than methionine which could be important for better availability for absorption. Zn-Gly can directly or indirectly influence the function of intestinal mucosa and improve the utilization of dietary energy. The immune response of chickens may be modified by the level of zinc in the diet. Supplementation of $\mathrm{Zn}$ in diets also improves intestinal morphology by increasing the villus height and reducing the crypt depth in animals $[4,10]$.

The National Research Council [9] recommended 40 ppm for broiler chickens, which appeared to be based on the results that considered growth performance as the only 
criterion [5, 12]. However, there are several reports that demonstrate that higher $\mathrm{Zn}$ levels [60-180 ppm] produce better immune growth performance and intestinal function of broiler chickens $[13,14]$.

These discrepancies prompted us to evaluate the morphology in the caudal part of jejunum after feed supplementation with different levels of organic and inorganic zinc.

\section{MATERIALS AND METHODS}

\section{Animals}

A total of 210 one-day-old ROSS 308 hybrid broilers (MACH Hydina Budmerice Ltd., Slovakia) of both sexes were randomly assigned into 5 treatment groups consisting of 6 replicate pens with 7 chickens in each pen. Dietary treatments included the unsupplemented basal diet (BD, Control) and the same BD supplemented with 30 or $70 \mathrm{mg} \cdot \mathrm{kg}^{-1}$ added $\mathrm{Zn}$ from $\mathrm{ZnSO}_{4} \cdot \mathrm{H}_{2} \mathrm{O}$ (Sigma-Aldrich, USA) or zinc chelate of glycine hydrate (Glycinoplex-Zn 26, Phytobiotics, Germany). Commercial broiler starter (1-19 days) and grower (20-39 days) diets were formulated as a basal diet (BD) with no supplemental zinc for the control treatment (Table 1). The mean analysed values of the $\mathrm{Zn}$ content in the starter and grower basal diets were 31.6 and $31.9 \mathrm{mg} . \mathrm{kg}^{-1}$, respectively. During the 40 -day feeding trial, all birds were offered the BD supplemented with two levels of the inorganic $\mathrm{Zn}$ source $\left(\mathrm{ZnSO}_{4} 30 \mathrm{mg} \cdot \mathrm{kg}^{-1}, \mathrm{ZnSO}_{4}\right.$ $70 \mathrm{mg} \cdot \mathrm{kg}^{-1}$ ) or organic Zn chelate (Gly-Zn $30 \mathrm{mg} \cdot \mathrm{kg}^{-1}$, Gly-Zn 70 mg.kg ${ }^{-1}$ ).

The birds were housed in large pens on wood shavings. The environmental temperature was kept at about $35^{\circ} \mathrm{C}$ during the first week and then was gradually reduced to reach a final temperature of about $24^{\circ} \mathrm{C}$. The broilers were exposed to $23 \mathrm{~h}$ constant light/ $1 \mathrm{~h}$ darkness light schedule and had free access to experimental diets and tap water throughout the experiment.

All procedures were in accordance with European Community guidelines (Directive 2010/63/EU) for animal experiments and the experimental protocol was approved by the Ethics Committee of the Institute of Animal Physiology of the Slovak Academy of Sciences and by the State Veterinary and Food Administration (Ro-4160/13-221).
Table 1. Composition of the basal diets (BD)

\begin{tabular}{|c|c|c|}
\hline $\begin{array}{c}\text { Ingredient } \\
{[\%]}\end{array}$ & $\begin{array}{l}\text { Starter diet } \\
\text { (Days } 1 \text { to 19) }\end{array}$ & $\begin{array}{l}\text { Grower diet } \\
\text { (Days } 20 \text { to 39) }\end{array}$ \\
\hline Wheat, ground & 30.96 & 26.56 \\
\hline Maize, ground & 35.00 & 45.00 \\
\hline $\begin{array}{l}\text { Soybean meal, } \\
\text { extracted }\end{array}$ & 28.20 & 25.00 \\
\hline Fish meal & 2.50 & - \\
\hline $\begin{array}{l}\text { Monocalcium } \\
\text { phosphate }\end{array}$ & 0.90 & 0.95 \\
\hline Limestone & 1.70 & 1.70 \\
\hline Feed salt & 0.35 & 0.36 \\
\hline Coccidiostat & 0.05 & 0.05 \\
\hline Lysine & 0.10 & 0.10 \\
\hline Methionine & 0.16 & 0.20 \\
\hline Vitamin premix a & 0.04 & 0.04 \\
\hline Mineral premix b & 0.04 & 0.04 \\
\hline \multicolumn{3}{|c|}{ Nutrient composition } \\
\hline $\begin{array}{l}\text { Dry matter } \\
{\left[\mathrm{g} . \mathrm{kg}^{-1}\right]}\end{array}$ & 883.02 & 881.55 \\
\hline $\begin{array}{l}\text { Crude protein } \\
{\left[\mathrm{g} \cdot \mathrm{kg}^{-1}\right]}\end{array}$ & 210.75 & 182.19 \\
\hline $\begin{array}{l}\text { Crude fat } \\
{\left[g^{\left.-k^{-1}\right]}\right.}\end{array}$ & 28.27 & 27.44 \\
\hline $\begin{array}{l}\text { Crude fibre } \\
{\left[\mathrm{g} \cdot \mathrm{kg}^{-1}\right]}\end{array}$ & 30.85 & 29.97 \\
\hline $\begin{array}{l}\text { Lysine } \\
{\left[\mathrm{g}^{\mathrm{kg}} \mathrm{kg}^{-1}\right]}\end{array}$ & 12.10 & 9.90 \\
\hline $\begin{array}{l}\text { Methionine } \\
{\left[\mathrm{g} . \mathrm{kg}^{-1}\right]}\end{array}$ & 5.09 & 4.89 \\
\hline $\begin{array}{l}\text { Zinc } \\
{\left[\mathrm{mg} \cdot \mathrm{kg}^{-1}\right]}\end{array}$ & 31.64 & 31.86 \\
\hline $\begin{array}{l}\text { Manganese } \\
{\left[\mathrm{mg} \mathrm{kg}^{-1}\right]}\end{array}$ & 90.99 & 88.48 \\
\hline $\begin{array}{l}\text { Copper } \\
{\left[\mathrm{mg} \cdot \mathrm{kg}^{-1}\right]}\end{array}$ & 14.23 & 13.58 \\
\hline 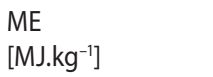 & 12.08 & 12.24 \\
\hline
\end{tabular}

The vitamin premix provided per kg of diet: vitamin A $12.000 \mathrm{IU}$; vitamin D3 4000.0 IU; vitamin K $3.0 \mathrm{mg}$; vitamin E $45.5 \mathrm{mg}$; vitamin B1 $2.0 \mathrm{mg}$; vitamin B2 6.0 mg; vitamin B6 4.0 mg; vitamin B12 0.02 mg; niacin $40.0 \mathrm{mg}$; pantothenic acid $12.0 \mathrm{mg}$; biotin $0.2 \mathrm{mg}$; folic acid $1.5 \mathrm{mg}$.

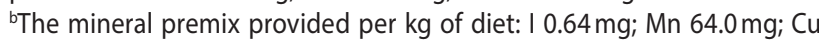
$6.4 \mathrm{mg}$; Se $0.1 \mathrm{mg}$; Fe $48.0 \mathrm{mg}$. 


\section{Sample collection}

After the 40-day feeding period, two birds from each replicate (12 birds/group) were slaughtered for sample collection. Tissue samples from the terminal section of the jejunum were collected for the determination of villus height and surface area.

\section{Intestinal histomorphology}

Jejunum samples were fixed in $10 \%$ neutral buffered formalin and prepared using paraffin embedding techniques. Three consecutive sections $(5 \mu \mathrm{m})$ from each jejunum were stained using haematoxylin and eosin and observed for histomorphology. The villus height and its area (from the tip of the villus to the crypt opening) were measured from 70 to 100 randomly selected villi with one section per chicken at 100× magnification (Fig. 1). The morphometry was evaluated using the NIS-Elements Advanced Research 3.0 Programme (commercial purchased programme).

\section{Statistical analysis}

Statistical analysis of the data was done by one-way analysis of variance (ANOVA) with the post hoc Tukey multiple comparison test using GraphPad Software (USA). The differences between the mean values for the different treatment groups were considered statistically significant at $\mathrm{P}<0.05, \mathrm{P}<0.01$ and $\mathrm{P}<0.001$. The values are expressed as means \pm standard deviation (SD).

\section{RESULTS}

\section{Intestinal morphometry}

The dietary $\mathrm{Zn}$ supplementation increased the villus height of the jejunum in both groups fed the diets enriched with inorganic $\mathrm{Zn}$ source $\left(\mathrm{ZnSO}_{4} 30 \mathrm{mg}, \mathrm{ZnSO}_{4} 70 \mathrm{mg} \cdot \mathrm{kg}^{-1}\right)$ and also in Gly-Zn 70 mg. $\mathrm{kg}^{-1}$ group $(\mathrm{ab} \mathrm{P}<0.001)$ compared to the BD and Gly-Zn $30 \mathrm{mg} \cdot \mathrm{kg}^{-1}$ groups (Table 2).
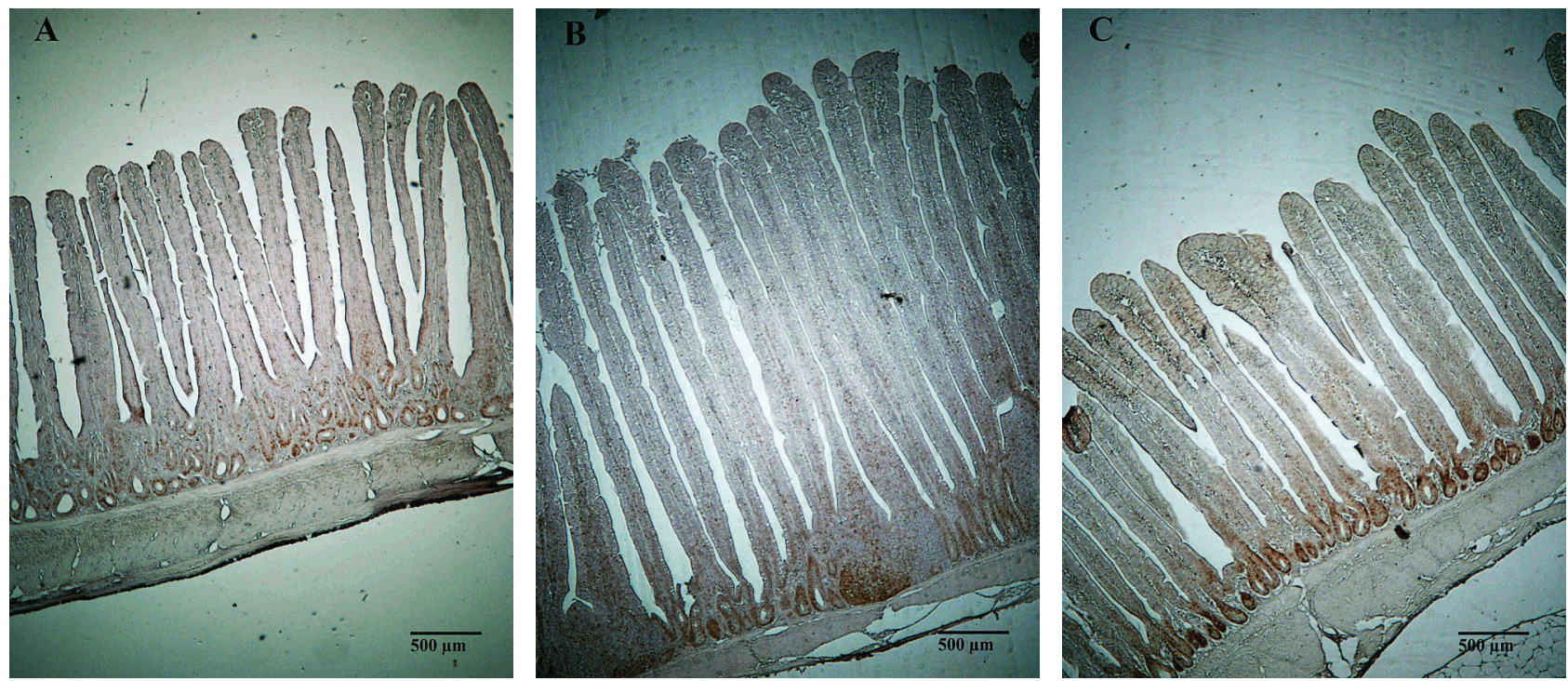

Fig. 1. Histological sections of the jejunum of broilers supplemented with different amount and $\mathrm{Zn}$ source (A) - BD; (B) - ZnSO 30 mg.kg-1 (C) - Gly-Zn 70 mg.kg-1

Table 2. Effect of Zn supplementation on the histomorphology of the jejunum in broilers

\begin{tabular}{|c|c|c|c|c|c|}
\hline Group & BD & $\mathrm{ZnSO}_{4} .30 \mathrm{mg}^{-1}$ & $\mathrm{ZnSO}_{4 .} 70 \mathrm{mg}^{-1}$ & Gly-Zn.30mg ${ }^{-1}$ & Gly-Zn.70 mg \\
\hline $\begin{array}{l}\text { Villus height } \\
\qquad[\mu \mathrm{m}]\end{array}$ & $1284 \pm 180^{\text {bd }}$ & $1462 \pm 360^{a}$ & $1492 \pm 330^{a}$ & $1204 \pm 240^{b}$ & $1376 \pm 310^{c}$ \\
\hline $\begin{array}{c}\text { Villus surface } \\
{\left[\mu^{2}\right]}\end{array}$ & $152^{3} \pm 680^{f}$ & $192^{3} \pm 1370^{a e}$ & $184^{3} \pm 910^{a}$ & $160^{3} \pm 580^{\mathrm{bd}}$ & $184^{3} \pm 640^{c}$ \\
\hline
\end{tabular}

All values are expressed as means \pm SD. Means with different superscripts within a row differ significantly (ab $-P<0.001$; $^{\text {cd }}-\mathrm{P}<0.01$ ef $\left.^{-} \mathrm{P}<0.05\right)$ 
The villus height was higher in the group Gly-Zn 70 mg. $\mathrm{kg}^{-1}$ (cd $\mathrm{P}<0.01$ ) compared to the jejunal villi of broilers fed the BD only.

Low-dose supplementation with inorganic $\mathrm{Zn}$ source $\left(\mathrm{ZnSO}_{4} 30 \mathrm{mg} \cdot \mathrm{kg}^{-1}\right)$ led to the increase of the villus surface area in compare to the $\mathrm{BD}$ ( $\mathrm{efP}<0.05$ ) and Gly-Zn 70 mg.kg ${ }^{-1}$ groups $(\mathrm{ab} \mathrm{P}<0.001)$. Similarly, the higher villus surface area was measured in the $\mathrm{ZnSO}_{4} 70 \mathrm{mg} \cdot \mathrm{kg}^{-1}$ group (ab $\mathrm{P}<0.001)$ compared to the Gly-Zn $30 \mathrm{mg} \cdot \mathrm{kg}^{-1}$ as well as in the group Gly-Zn $70 \mathrm{mg} \cdot \mathrm{kg}^{-1}(\mathrm{~cd} \mathrm{P}<0.01)$ compared to Gly-Zn 30 mg.kg-1.

\section{DISCUSSION AND CONCLUSIONS}

Zinc is known to influence the intestinal morphology and improve absorptive capacity, and enhance growth performance $[5,6]$. Moreover, zinc is essential for cell proliferation and differentiation, especially for the regulation of DNA synthesis and mitosis [2). Southon et al. [11] demonstrated that $\mathrm{Zn}$ deficiency in rats is accompanied with a reduction of the jejunal villus height, while a short period of zinc supplementation returned the morphology into its normal condition in experimental animals. On the other hand, 42-day-old chickens fed the diet supplemented with $90 \mathrm{mg} \cdot \mathrm{kg}^{-1} \mathrm{Zn}$-Gly increased the villus height and decreased the crypt depth of the jejunum [5]. In our experiments, the intake of both diets supplemented with the inorganic $\mathrm{Zn}$ source and also with the higher-dose organic chelate of zinc (Gly-Zn $70 \mathrm{mg} \cdot \mathrm{kg}^{-1}$ ) increased the height of the jejunal villi. Similarly, the surface villus area followed the same pattern as the height of the villi. It should be stressed that the villus height and surface villus area of broilers fed the diet with the addition of $70 \mathrm{mg} \cdot \mathrm{kg}^{-1}$ of $\mathrm{Zn}$ chelate reached the similar value of both morphometric parameters as the broilers supplemented with the lowdose inorganic source of zinc.

The height of villi and their area can influence the source of supplemented zinc in diets [8]. It is known, that organic zinc chelate used in our trial improves zinc absorption comparing to the inorganic form of zinc. The absorption difference of zinc between the organic and inorganic forms can influence the growth of the intestinal villi. Our results suggest that organic zinc chelate after part absorption, supported better growth of the villi after supplementation of the diet with higher doses of organic zinc chelate.
On the other hand, recently published immunological parameters from that experiment $[3,7]$ as quantification of the expression of MUC-2, IgA gene, and evaluation of secretory $\operatorname{IgA}$ in the lumen of the intestine, resulted in better affects found in birds fed diet supplemented with low doses of organic source of zinc.

In conclusion, our results demonstrated that an inorganic zinc source increased the height of villi and surface area of villi already after supplementation of feed with a low dose of zinc. On the other hand, the positive effect on the growth of villi was seen only after administration of a high dose of organic zinc in the feed. The villus surface was higher in all groups receiving the $\mathrm{Zn}$ supplements in comparison to just the basal diet.

\section{ACKNOWLEDGEMENTS}

This study was supported by the Slovak Research and Development Agency under the contracts No. APVV-15-0165, VEGA 1/0575/16, VEGA 1/0562/16, and Centrum of excellences for infectious disease and zoonosis (Operational program of research and development) financed by EU funds for the regional improvement.

\section{REFERENCES}

1. Bao, Y.M., Choct, M., Iji, P.A., Bruerton, K., 2010: The digestibility of organic trace minerals along the small intestine in broiler chickens. Asian-Australasian J. Anim. Sci., 23, 90-97.

2. Beyersmann, D., Haase, H., 2001: Functions of zinc in signalling, proliferation and differentiation of mammalian cells. BioMetals, 14, 331-341.

3. Bobíková, K., Levkut, M., Jr., Husáková, E., Levkutová, M., Kissová, V., Ivanišinová, O., et al., 2016: Effect of glycin-zinc complex on mucin and IgA expression, secretory IgA concentration and lengths of intestinal villi in chickens. J. Comp. Pathol., 154, 81.

4. Burrell, A.L., Dozier, W. A., Davis, A. J., Compton, M.M., Feeman, M.E., et al., 2004: Responses of broilers to dietary zinc concentrations and sources in relation to environmental implications. British Poult. Sci., 45, 225-263.

5. Feng, J., Ma, W. Q., Niu, H. H., Wu, X. M., Wang, Y., Feng, J., 2010: Effects of zinc glycine chelate on growth, haematologi- 
cal, and immunological characteristics in broilers. Biol. Trace Elem. Res., 133, 2003-2011.

6. Katouli, M., Melin, L., Jensen-Waern, M., Wallgren, P., Möllby, R., 1999: The effect of zinc oxide supplementation on the stability of the intestinal flora with special reference to composition of coliforms in weaned pigs. J. Appl. Microbiol., $87,564-573$.

7. Levkut, M., Jr., Husáková, E., Bobíková, K., Karaffová, V., Levkutová, M., Ivanišinová, O., et al., 2017: Inorganic or organic zinc and MUC-2, IgA, IL-17, TGF- $\beta 4$ gene expression and sIgA secretion in broiler chickens. Food Agricult. Immunol., 28, 801-811.

8. Lönnerdal, B., 2000: Dietary factors influencing zinc absorption. J. Nutr., 130, 1378S-1383S.

9. National Research Council, 1994: Nutrient Requirements of Poultry. 9th edn., Washington, DC, National Academic Press, $157 \mathrm{pp}$.

10. Payne, R.L., Bidner, T.D., Fakler, T.M., Southern, L.L., 2006: Growth and intestinal morphology of pigs from sows fed two zinc sources during gestation and lactation. J. Anim. Sci., 84, 2141-2149.
11. Southon, S., Gee, J.M., Bayliss, C.E., Wyatt. G.M., Horn, N., Johnson, I. T., 1986: Intestinal microflora, morphology and enzyme activity in zinc-deficient and $\mathrm{Zn}$-supplemented rats. Br. J. Nutr., 55, 603-611.

12. Sunder, G. S., Panda, A.K., Gopinath, N.C.S., Rama Rao, S. V., Raju, M.V.L.N., Reddy, M.R., et al., 2008: Effects of higher levels of zinc supplementation on performance, mineral availability, and immune competence in broiler chickens. J. Appl. Poult. Res., 17, 79-86.

13. Tang, Z., Wen, C., Li, P., Wang, T., Zhou, Y, 2014: Effect of zinc-bearing zeolite clinoptololite on growth performance, nutrient retention, digestive enzyme activities, and intestinal function of broiler chickens. Biol. Trace Elem. Res., 158, $51-57$.

14. Wenqiang, M.A., Niu, H., Feng, J., Wang, Y., Feng, J., 2011: Effect of zinc glycine chelate on oxidative stress, contents of trace elements, and intestinal morphology in broilers. Biol. Trace Elem. Res., 142, 546-556.

15. Yu, Y., Lu, L., Wang, R. L., Xi, L., Luo, X. G., Liu, B., 2010: Effects of source and phytate on zinc absorption by in situ ligated intestinal loops of broilers. Poult. Sci., 89, 1146-1155.

Received May 17, 2017

Accepted August 17, 2017 